\title{
PENGARUH PENGUASAAN IT GURU TERHADAP KUALITAS PEMBELAJARAN DIMASA PANDEMI
}

\author{
Novia Ayya Shofia ${ }^{1}$, Eva Luthfi Fakhru Ahsani \\ ${ }^{1}$ Institut Agama Islam Negeri Kudus \\ e-mail: ${ }^{1}$ noviaayyashofia20@gmail.com, ${ }^{2}$ evaluthfi@iainkudus.ac.id
}

\begin{abstract}
The purpose of this study is to find out the reader regarding the importance of the influence of teacher's IT mastery on the quality of learning during this pandemic, because of covid-19 causing all learning to be done online, with this if the teacher does not have expertise in the IT field, learning becomes constrained. For this reason, the author raises this title with the aim that the skills of teachers in making and delivering teaching materials using technology-based learning media can be improved and learning is not constrained even though it is only through virtual. This type of research uses descriptive qualitative research. The results of the study are used to show that technology has an important role in the implementation of learning during a pandemic like this, therefore it is important for educators to be able to master technology. Because technology plays a role as a medium in interacting between educators and students in the implementation of online learning so that the learning process is not hampered due to technology that makes it easier for students to still study even though it is not carried out face-to-face. In the implementation of online learning, there are challenges for educators who must be prepared in various ways so that the knowledge provided can be understood and accepted by students even though it is virtual. Other obstacles to online learning include signal constraints, declining attitude values, low knowledge and readiness of technological facilities and infrastructure.
\end{abstract}

Keywords: Influence; IT Teacher; Quality of learning; Pandemic

\begin{abstract}
Abstrak
Tujuan penelitian ini adalah guna mengetahui pembaca terkait pentingnya pengaruh penguasaan IT guru terhadap kualitas pembelajaran pada masa pandemi ini, karena dari covid-19 mengakibatkan seluruh pembelajaran dilakukan secara daring, dengan ini jika guru tidak memiliki keahlian dalam bidang IT membuat pembelajaran jadi terkendala. Untuk itu penulis mengangkat judul ini dengan tujuan agar keterampilan guru dalam membuat maupun menyampaikan materi ajar menggunakan media pembelajaran berbasis teknologi dapat meningkat serta pembelajaran tidak terkendala walaupun hanya melalui virtual. Jenis penelitian ini menggunakan penelitian kualitatif deskriptif. Hasil penelitian digunakan untuk menunjukkan teknologi mempunyai peran yang penting terhadap pelaksanaan pembelajaran dimasa pandemi seperti ini maka dari itu pentingnya bagi pendidik untuk bisa menguasai teknologi. Karena teknologi berperan sebagai media dalam melakukan interaksi antara pendidik dan peserta didik dalam pelaksanaan pembelajaran daring sehingga proses pembelajaran tidak terhambat dikarenakan adanya teknologi yang memudahkan para pelajar masih bisa menuntut ilmu meskipun tidak dilaksanakan secara tatap muka. Dalam pelaksanaan pembelajaran daring ini terdapat tantangan tersendiri bagi para pendidik yang harus siap berbagai cara agar ilmu yang diberikan dapat dipahami dan diterima bagi peserta didik meskipun melalui virtual. Hambaatan yang lain dari pembelajaran daring ini seperti terkendala sinyal, nilai sikap semakin menurun, rendahnya pengetahuan serta kesiapan sarana dan prasarana teknologi.
\end{abstract}

Kata kunci: Pengaruh; IT Guru; Kualitas Pembelajaran; Pandemi

\section{PENDAHULUAN}

Akibat adanya virus corona diseluruh dunia salah satunya di Indonesia mengakibatkan negara-negara menetapakan berbagai kebijakan salah satunya di Indonesia yang menetapkan kebijakan Pembatasan Sosial Berskala Besar (PSBB) yang diberlakukan di setiap daerah. Kebijakan tersebut menjadikan adanya perbahan- 
perubahan besar di berbagai bidang salah satunya pendidikan (Khamim, 2020). Di dalam dunia Pendidikan kemndikbud berupaya agar para pelajar serta para pendidik dapat melakukan kegiatan belajar mengajar walapun melalui cara yang berbeda. Kemendikbud menetapkan aturan baru bahwa Pendidikan di Indonesia tetap diselenggarakan, namun dengan sistem berbeda yaitu Study From Home (SFH). Hal ini tidak mudah dilaksanakan karena dibutuhkan kerja sama anatara guru dengan orang tua untuk membimbing siswa.

Tidak hanya peran dari guru, tetapi peran orang tua jadi aspek yang penting dalam pembelajaran online. orang tua harus senantiasa memberikan arahan, edukasi, serta pengawasan yang baik terhadap anaknya. Akibat adanya pembatasan ini membuat para sekolah sampai dengan perguruan tinggi diliburkan dan diganti dengan media pembelajaran berbasis online atau daring. Pembelajaran jarak jauh ini sudah ditentukan oleh pemerintah dengan tujuan diadakannya pembelajaran jarak jauh ini guna memutus rantai penyebaran virus corona. Walaupun hanya melalui daring tetapi peserta didik masih bisa menjalakan kegiatan menuntun ilmu secara online dengan media teknologi yang semakin canggih serta dengan arahan dan bimbingan guru para siswa masih tetap bisa menerima pembelajaran yang disampaikan oleh bapak ibu guru. (Ahsani, 2020)

Pada pelaksanaan pembelajaran daring ini membutuhkan peran teknologi sebagai proses pembelajaran agar dapat terlaksananya pedidikan jarak jauh, namun yang jadi masalah ialah tidak semua para pelajar mempunyai alat tekologi misal hp maupun laptop, serta keterbatasan kuota maupun sinyal yang sulit bisa menghambat lancarnya pembelajaran daring. Tidak hanya para pelajar saja yang mengalami problematika tetapi para orang tua serta guru yang masih minim dalam pengetahuan dan penggunaan teknologi. Dengan adanya pembelajaran daring membuat tantangan tersendiri bagi para pendidik, peserta didik serta para orang tua dan masyarakat luas.

Dengan ini para pendidik harus mencari cara bagimana agar proses pembelajaran yang disampikan pendidik dapat diterima dengan mudah oleh peserta didik. Bukan hanya pendidik saja, para peserta didik harus dapat menyesuakian dengan adanya situasi seperti ini. Dalam pelaksaan pembelajaran daring ini tentunya menuntut para pendidik harus bisa menguasai teknologi agar proses pembelajaran dapat berjalan dengan lancar. Lalu bagimana dengan guru yang tidak pandai mengoprasikan komputer alias gagap teknologi? Masih banyak guru diluar sana yang masih gagap dengan teknologi dikarenakan ketidaktahuan dengan kemajuan teknologi yang ada saat ini apalagi dengan keadaan pandemi seperti ini yang segalanya berubah menjadi serba teknologi. Maka dari itu, guru sebagai mediator Pendidikan harus selalu meningkatkan keprofesionalismenya seiring 
dengan teknologi yang semakin berkembang pesat di segala bidang, salah satunya bidang pendidikan.

Kemajuan teknologi kini mengalami perkembangan seiring dengan kemajuan zaman, terutama dalam bidang Pendidikan dengan adanya teknologi maka Pendidikan juga akan mengalami perubahan yang lebih moderen, berbdeda dengan zaman dahulu yang model serta media belajarnya masih dengan cara yang sederhana dan manual karena pada zaman dahulu hanya menggunakan papan tulis dari kayu dan kapur. Dibandingkan dengan zaman sekarang kini Pendidikan sangat berkembang pesat seiring dengan kemajuan teknologi yang semakin canggih, media Pendidikan zaman sekarang serba menggunakan kecanggihan dari teknologi seperti menampilkan proyekor dengan begitu guru tidak susah-susah menulis di papan tulis apalagi kini Pendidikan berubah derastis semenjak adanya pandemi karena hampir semua pembelajaran yang disampaikan menggunakan media teknologi. Tak hanya itu saja, pada zaman dahulu peserta didik memperoleh sumber belajar harus rajin ke perpustakaan untuk mencari sumber refrensi pembelajaran serta rajin membaca buku. Berbeda halnya dengan zaman sekarang karena peserta didik tinggal mencari materi dari internet serta youtube sudah terdapat berbagai artikel materi pembelajaran yang akan dituju. Sudah jelas, bahwa hampir semua peserta didik zaman sekrang sudah mahir dalam penggunaan teknologi. Namun, seorang guru juga diharuskan untuk tidak gagap teknologi, jika seorang guru sudah menguasai teknologi maka akan dengan mudah guru bisa menyesuaikan dengan situasi yang darurat seperti adanya pandemi ini karena dengan adanya pandemi seluruh aktivitas dilaksanakan dari rumah seperti halnya pembelajaran daring guna memutus rantai persebaran virus corona, tidak bisa dibayangkan jika guru tidak mampu menguasai serta menggunakan teknologi maka proses pembelajaran yang dilaksanakan secara daring akan mengalami kesulitan dan tentunya akan terhambat. Saat itulah, teknologi semakin menjadi kebutuhan penting untuk peserta didik maupun guru.

Guru harus profesional sesuai dengan amanat UU yang sudah ditetapkan dan guru dapat memadukan teknologi dalam pembelajaran, sehingga dapat meningkatkan stimulus siswa dalam belajar menjadi tinggi, dengan demikian sangat berpengaruh baik terhadap prestasi belajar siswa. Maka dari itu pengaruh penguasaan IT guru terhadap kualitas pembelajaran dimasa pandemi ini sangat penting dalam meningkatkan kualitas serta mutu Pendidikan. Dengan adanya teknologi dimasa pandemi dapat mempermudah dalam proses belajar mengajar jarak jauh sehingga dapat mencapai tujuan Pendidikan yang diinginkan. 


\section{METODE PENELITIAN}

Artikel ilmiah ini disusun dengan menggunakan metode dan langkah-langkah sistematis yang bertujuan memudahkan penelitian. Jenis penelitian yang digunakan adalah kualitatif deskriptif melalui kajian Pustaka yang berdasarkan studi literatur. Peneliti menggunakan bentuk penelitian kualitatif deskriptif, sumber data yang digunakan dalam penelitian ini adalah Teknik kepustakaan ( library research ). Maka dari itu sumber data yang digunakan dalam penelitian ini mengambil dari bahan-bahan tertulis seperti buku-buku, jurnal, artikel dan berbagai literatur lainnya yang sesuai dengan penelitian yang sedang dibahas terkait Pengaruh Penguasaan IT Guru Terhadap Kualitas Pembelajaran Dimasa Pandemi.

\section{HASIL DAN PEMBAHASAN}

Menurut (Suryana, 2012) teknologi ialah perkembangan suatu media/ perlengkapan yang bisa digunakan dengan lebih efektif guna memproses dan mengatur suatu permasalahan. Hal ini dapat dikatakan bahwa teknologi bisa menjadi suatu wadah untuk meningkatkan kealihan/ kualitas seseorang menuju suatu perubahan. Salah satu manfaat yang diperoleh dengan hadirnya teknologi yakni bisa menaggulangi masalahmasalah yang ada. Sangat disayangkan, apabila seorang sangat acuh terhadap hadirnya teknologi. Akibatnya, seseorang tersebut menjadi tertinggal serta tidak bisa mengikuti suatu perubahan. Keberadaan teknologi jadi suatu bagian yang berpengaruh terutama pada dunia pendidikan.

Menurut KBBI, teknologi pendidikan merupakan tata cara bersistem buat merencanakan, memakai, serta memperhitungkan segala aktivitas Pendidikan serta pembelajaran dengan mencermati, baik dengan teknis ataupun interaksi antara keduanya, sehingga memperoleh wujud pembelajaran yang efisien. Teknologi pendidikan merupakan suatu aplikasi buat menolong proses pembelajaran serta mengembangkan kinerja dengan memakai, serta merawat proses serta teknologi yang memadai.

Teknologi memiliki peran yang sangat penting dimasa pandemi seperti ini. Sebab seluruh kegiatan yang semula dilakukan secara langsung saat ini beralih hampir seluruh proses dilakukan dengan menggunakan teknologi. Dengan merabaknya virus covid-19 ini membuat seluruh masyarakat tidak hanya di Indonsia namun diseluruh dunia diharuskan untuk tidak berkontak langsung dengan orang lain, sebab virus ini sangat gampang penularannya dan sampai menimbulkan kematian. Untuk itu pemerintah membuat 
peraturan kebijakan yang sangat tegas untuk memutus rantai penyebaran virus ini, di antaranya menjaga jarak, sering mencuci tangan bahkan para pekerja serta anak sekolah diharuskan untuk melaksanakan kegiatannya di rumah. Dengan adanya peraturan ini maka jalan satu- satunya adalah dengan teknologi. Adanya teknologi ini sangat mempermudah kita khusunya bagi para pelajar masih dapat mengikuti pembelajaran walapun hanya melalui virtual.

Teknologi informasi serta komunikasi mempunyai peran yang sangat penting pada dunia Pendidikan saat ini. Dengan adanya pembelajaran daring ini teknologi menjadi media guru untuk menyampaikan sebuah materi pembelajaran yang akan diberikan kepada muridnya. Dengan adanya teknologi ini sangat memudahkan bagi kita semua untuk memperloleh sesuatu misalnya mendapatkan informasi, sebagai media pembelajaran berbasis online dan masih banyak lagi manfaatnya. Dengan semakin berkembangnya teknologi membuat proses pembelajaran online menjadi sangat gampang karena teknologi mempunya berbagai media aplikasi yang bisa digunakan untuk proses pembelajaran diantaranya ada Google from, zoom, Google meet, Google Classroom dan masih banyak lagi. Dengan adanya semua aplikasi tersebut maka pembelajaran akan bisa berlangsung.

Hal ini tentu menjadi solusi yang tepat terkait adanya kebijakan yang mewajibkan pendidik serta siswa menyelenggarakan pembelajaran secara daring (e-learning). Elearning ialah proses pendidikan yang tidak mewajibkan pendidik serta siswa untuk bertatap muka secara langsung seperti pada metode konvesional yang harus dilangsungkan di dalam ruang kelas (Sukmawati, Nensia. 2019). Menjadikan siswa bisa melaksanakan proses belajar dimana dan kapan saja sesuai waktu yang diinginkan, sekaligus melatih siswa buat belajar mandiri dalam mempelajari hal baru. Oleh karena itu, pendidik perlu mengetahui serta mencermati/ memperhatikan komponen - komponen penting yang dibutuhkan dalam melaksanakan e-learning.

Perkembangan teknologi memberikan pengaruh positif untuk kemajuan dunia pendidikan. Guru selaku pelaku utama sebagai pendidik harus mampu melakukan perkembangan serta mempraktikkan kemajuan teknologi supaya proses belajar mengajar mengasyikkan serta tidak membosankan. Guru wajib mengikuti kemajuan zaman yang semakin berkembang serta mampu menggunakan teknologi buat meningkatkan kompetensi yang disyaratkan dalam UU. Peraturan yang utama agar seorang guru sebagai pendidik agar lebih efisien dalam pembelajaran ialah dapat memahami kompetensi pedagogik, kompetensi kepribadian, kompetensi profesional, kompetensi sosial. 
Teknologi Pendidikan sudah banyak mberikan fasilitas untuk kemajuan kompetensi guru supaya bisa lebih berkembang dan efisien dalam melaksanakan pembelajaran.

Kompetensi profesional bisa diartikan sebagai keahlian guru buat memahami serta memanfaatkan berbagai macam sumber daya buat menunjang pendidikan, termasuk kemampuan buat memahami ilmu pengetahuan dan teknologi informasi serta komunikasi sesuai dengan kemajuan zaman. Guru memiliki peran yang sangat penting dalam jalannya Pendidikan, oleh sebab itu pengetahuan, keahlian dan kemampuan teknologi guna menunjang proses Pendidikan menjadi sesuatu hal yang bermanfaat untuk dikenal oleh guru saat ini (Tekege, 2017)

Guru wajib berhadapan dengan 4 isu penting di masa depan ialah: 1) menjadi orang - orang yang lebih kompetitif atas perkembangan global; 2) siap dalam meningkatkan mutu, inovasi, serta pelayanan; 3) mengisi usaha merger (penggabungan), serta akuisisi (penyediaan) aspek pengetahuan serta peluang; dan 4) melaksanakan teknologi informasi berbasis jaringan. Kemudian, terdapat 3 jenis pelaksanaan teknologi di bidang pendidikan: 1) untuk merancang suatu pembelajaran guru perlu menggunakan teknologi; 2) guru menggunakan teknologi buat presentasi; 3) guru menggunakan teknologi untuk mengerjakan tugas administrasi yang terpaut dengan profesinya, semacam evaluasi, pembuatan catatan, pelaporan, serta tugas pengelolaan (Nurhayati, T., 2016).

Namun, bagaimana jika seorang guru gagap teknologi dalam suatu proses pembelajaran? Gagap teknologi sama halnya dengan seorang yang tidak pandai mengoperasikan teknologi secara baik yang diakibatkan karena ketidaktahuan dengan kemajuan teknologi yang ada saat ini. Dalam berbagai hasil riset serta tulisan, mensinyalir ada sekitar $70 \mathrm{~s} / \mathrm{d}$ 90\% guru dalam pemanfaatan kemajuan TIK dalam proses pendidikan serta aktivitas lain dianggap masih gagap teknologi. Maka dari itu, pendidik selaku mediator pendidikan wajib selalu meningkatkan keprofesionalismenya bersamaan dengan teknologi yang semakin berkembang pesat di seluruh bidang, salah satunya bidang pendidikan. Guru harus profesional sesuai yang tertuang di dalam UU serta guru bisa memadukan teknologi dalam pembelajaran, sehingga dapat mengembangkan stimulus siswa dalam belajar menjadi tinggi, dengan demikian sangat mempengaruhi baik terhadap prestasi belajar siswa.

\section{Pengaruh IT Guru Terhadap Pembelajaran Di Masa Pandemi}

\section{Pengaruh IT Guru Di Bidang Pendidikan}


Seiring perkembangan zaman yang semakin maju, kini teknologi menjadi sorotan pertama dalam kemajuan zaman, dengan begitu kita dituntut untuk mampu mengikuti perkembangan zaman tersebut. Perkembangan teknologi pendidikan jadi aspek penting dalam menuntaskan permasalahan pembelajaran saat pandemi COVID-19. Oleh karena itu pentingnya seorang guru dalam menguasai teknologi Pendidikan sangat berpegaruh dengan situasi pandemi saat ini. Melaui teknologi Pendidikan bisa memudahkan kita dalam proses pembelajaran sehingga tidak terjadi hambatan. Ketika proses penyampaian pembelajaran yang diberikan oleh guru. Situasi pandemi saat ini maka teknologi adalah solusi yang tepat bagi kita semua terkhusus para pelajar karena teknologi mempunyai banyak manfaat serta fleksibel, karena dengan teknologi dapat menunjang pembelajaran secara mandiri saat ini.

Guru sebagai peran utama dalam Pendidik di sekolahan dituntut untuk bisa menguasai dan menggunakan IT. Karena dengan guru dapat menggunakan serta menguasai IT guru tersebut sudah dapat menerapkan persyaratan kompetensi guru di dalam UU yang telah ditentukan. Sedangkan semakin rendahnya kemampuan IT seorang guru, maka seorang guru tersebut tidak dapat mengimplementasikannya dan profesionalisme menjadi seorang guru akan bekurang. Jadi pengaruh IT bagi seorang guru sangat penting dalam bidang Pendidikan karena dengan perkembangan zaman semakin maju secara tidak langsung dalam bidang Pendidikanpun akan mengikuti sesuai perkembangan zaman tersebut dengan itu para pendidik dituntut untuk megenal serta dapat menggukan IT.

Keberhasilan aktivitas pendidikan pada sesuatu Sekolah dipengaruhi oleh bermacam aspek ialah, aspek guru, siswa, kurikulum, area sosial serta sebagainya. Guru jadi aspek berarti dalam proses pendidikan dengan tugas utama dalam menolong siswa supaya bisa belajar sesui kebutuhan serta minatnya. Upaya kenaikan kualitas pembelajaran tetap diteliti serta diupayakan lewat bermacam komponen pembelajaran. Semacam revisi serta penyempurnaan kurikulum, bahanbahan instruksional, sistem evaluasi, manajemen instruksional, seminar pembelajaran, proses belajar mengajar dan fasilitas serta prasarana yang menunjang kelancaran kegiatan pendidikan buat tingkatkan kualitas pembelajaran. Salah satu alternatif yang ditempuh guru dalam rangka kenaikan hasil pendidikan merupakan dengan memakai media IT dalam pendidikan. Pemakaian media yang pas serta bermacam- macam memiliki nilai instan, antara lain: menanggulangi keterbatasan pengalaman siswa, mengkongkritkan pesan yang abstrak, menanamkan konsep dasar yang pas, memunculkan keseragaman supaya bisa tingkatkan 
daya guna serta efisiensi dalam aktivitas pendidikan sehingga bisa tingkatkan kualitas pendidikan.( Rahmayanti, 2015).

Pertumbuhan teknologi serta komunikasi( TIK) sudah membagikan pengaruh terhadap dunia pembelajaran spesialnya dalam proses pendidikan. Bagi Rosenberg( 2001), dalam jurnal ( Ibnu Rusydi, 2017) dengan berkembangnya pemakaian TIK terdapat 5 perpindahan dalam proses pendidikan ialah:( 1) dari pelatihan ke penampilan,( 2) dari ruang kelas ke di mana serta kapan saja,( 3) dari kertas ke“ on line" ataupun saluran,( 4) sarana fisik dan ke sarana jaringan kerja,( 5) dari waktu siklus ke waktu nyata. Komunikasi selaku media pembelajaran dicoba dengan memakai media- media komunikasi semacam telepon, pc, internet, e- mail, serta sebagainya. Interaksi antara guru serta siswa tidak cuma dicoba lewat ikatan tatap muka namun pula dicoba dengan memakai media- media tersebut. Aktivitas pendidikan yang efisien membutuhkan sesuatu media yang menunjang penyerapan data sebanyak- banyakanya. Bersamaan dengan pertumbuhan jaman, hingga teknologi data berfungsi berarti selaku fasilitas buat memperoleh sumber data sebanyak- banyaknya yang berhubungan dengan modul pelajaran yang diajarkan. Tak hanya menguasai IT saja melainkan guru harus bisa memahamkan konsep pembelajaran bagi siswanya, agar dapat memudahkan siswa dalam menangkap pelajaran yang disampaikan. Konsep pemahaman pembelajaran ini sangat penting karena jika hanya bisa IT tetapi siswa tersebut tidak mampu memahami pembelajaran maka hasilnya juga akan mengecewakan. Untuk itu seorang guru harus dapat merancang sabaik-baiknya proses pembelajaran, karena siswa tidak hanya sekedar diberikan konten video tetapi juga pengarahan dalam memahami konep pembelajaran tersebut. (Hamidaturrohmah \& Mulyani, 2020).

Adapun yang dapat disimpulkan dari berbagai pendapat sumber diatas terhadap pengaruh IT guru dalam bidang Pendidikan di antaranya : Pertama, Dengan kemajuan teknologi yang berkembang secara terus menerus menyebabkan perubahan dalam cara belajar pendidik dalam proses pembelajaran seperti menggukan proyektor dan laptop. Kedua, dalam proses pembelajaran juga mengalami perubahan yang biasanya pembelajaran dilaksanakan disekolahan kini beralih pembelajaran secara jarak jauh atau berbasis online. Dengan bermodalkan teknologi yang menggunakan sebuah aplikasi pembelajaran sehingga dapat menghubungkan antara peserta didik dan pendidik serta dapat berkomunikasi diwaktu yang bersamaan. Ketiga, dengan adanya teknologi yang semakin canggih maka terciptanya model serta metode pembelajaran yang lebih kreatif dan inovatif yang dapat memudahkan siswa dalam proses pembelajaran yang diberikan 
oleh guru. Keempat, dengan adanya perkembangan teknologi mangalami perubahan yang pesat di bidang Pendidikan karena untuk menyesuaikan perkembangan zaman yang semakin maju untuk itu kurikulum Pendidikan juga mengalami perubahan yang mana peserta didik juga harus dapat menyesuaikan dengan perubahan tersebut.

Berbagai Pengaruh IT Terhadap Pembelajaran Di Masa Pandemi ini bisa dirasakan, terntunya memberikan dampak yang baik karena dengan adanya pandemi kita diharuskan untuk bisa menggunkan teknologi terkhusus bagi seseorang yang merasa gagap teknologi untuk terus belajar, berkembang, serta terus membuat perubahan untuk menjadi generasi yang berpengetahuan luas. Tak hanya sebagai peserta didik yang diharuskan dapat menguasai teknologi tetapi guru juga dituntut untuk bisa beradaptasi dengan situasi yang saat ini terjadi guna menciptakan pembelajaran yang optimal yang berbasis media online.

\section{Pengaruh IT Guru Di Bidang Kompetensi Pedagogik}

Kompetensi utama yang wajib dipunyai guru supaya pendidikan yang dicoba efisien serta dinamis merupakan kompetensi pedagogik. Secara pedagogis, kompetensi guru dalam mengelola pendidikan butuh memperoleh atensi yang sungguh- sungguh. Guru ialah tokoh utama dalam pendidikan, bertanggung jawab terhadap perencanaan, penerapan serta evaluasi pergantian ataupun revisi program pendidikan selaku usaha buat tingkatkan kualitas pembelajaran. Kompetensi pedagogik dalam Standar Nasional Pembelajaran, uraian pasal 28 ayat 3 butir( a) merupakan keahlian mengelola pembelajaran peserta didik yang meliputi pemahaman terhadap peserta didik, perencanaan serta penerapan pendidikan, penilaian hasil belajar, serta pengembangan peserta didik buat mengaktualisasikan bermacam kemampuan yang dipunyai.

Kompetensi pedagogik berarti dipunyai oleh guru sebab bisa menguasai sifatsifat, kepribadian, tingkatan pemikiran, pertumbuhan raga ataupun psikis peserta didik. Tidak hanya itu, guru bisa pula meningkatkan keahlian cocok kemampuan yang dipunyai oleh peserta didik. Guru yang kompeten dalam pemanfaatan TIK dibutuhkan buat meningkatkan kompetensi personal, pedagogis, sosial, serta professional cocok dengan Permendiknas Nomor 16 Tahun 2007 tentang Kompetensi Guru. Apabila guru sudah memahami TIK dengan baik hingga hendak pengaruhi tingkatan kompetensi pedagogik sehingga pendidikan lebih aktif serta inovatif. Perihal lain yang bisa pengaruhi kenaikan kompetensi pedagogik guru merupakan pengalaman mengajar guru. Terus menjadi lama pengalaman mengajar guru hingga terus menjadi baik pula penerapan tugas- tugas yang 
dipercayakan kepadanya. Periset berasumsi kalau yang bisa pengaruhi kompetensi pedagogik ialah kemampuan teknologi data komunikasi serta pengalaman mengajar.

Di sinilah kedudukan teknologi dapat dimainkan buat menolong kelancaran penyampaian pendidikan supaya tujuan pendidikan bisa tersampaikan serta dimengerti oleh peserta didik. Guru menggunakan bermacam media yang ada. Memakai media berbasis data sehingga pendidikan lebih mengasyikkan. Dalam pendidikan, guru wajib memakai media dengan menggunakan teknologi dalam perencanaan pendidikan, penyampaian modul, pemberian tugas- tugas, sampai proses evaluasi. Guru dapat menggunakan sumber- sumber belajar dalam jaringan yang telah banyak ada. Guru di tuntut aktif buat belajar kembali terpaut pemakaian teknologi dalam pendidikan, mengingat tiap partisipan didik memiiki style belajar tiap- tiap. Macam style belajar yang dipunyai wajib dapat dimengerti oleh guru serta setelah itu diterjemahkan dalam rangkaian pendidikan dengan memilah media teknologi yang pas.

\section{Pengaruh Positif dan Negatif Teknologi Terhadap Pendidikan}

\section{Pengaruh Positif TI Terhadap Pendidikan :}

Adapun pengaruh positif IT terhadap pendidikan adalah Pertama, munculnya jaringan internet, lab. Komputer disekolah dan teknologi lainnya merupakan suatu sumber pembelajaran dan media pendidikan. Dampak dari hal itu ialah meskipun peserta didik sudah mendapatkan materi yang diberikan oleh guru. para pendidik juga bisa mencari tambahan materi pembelajaran serta mencari sumber belajar lewat internet. Adanya teknologi membuat inovasi bagi pendidik untuk terus menggali ilmu pengetahuan supaya pembelajaran tidak meluluh yang diajarkan oleh guru saja tetapi bisa lebih mendalami ketika kita mencari banyaknya sumber pembelajaran. Tugas guru bukan sekedar mengajar dan memberikan materi pembelajaran melainkan membimbing siswanya untuk terus mengarahkan pendidikan ke hal positif dalam menggunakan media teknologi dan komunikasi. Kedua, dengan adanya IT memunculkan metode-metode pembelajaran yang lebih canggih guna memudahkan guru serta siswa dalam proses pembelajaran. Dampaknya, dengan adanya IT memunculkan berbagai metode metode yang memudahkan kita dalam proses pembelajaran serta memudahkan kita untuk memahami suatu pembelajaran tersebut supaya tidak membosankan ketika metode pembelajaran bervariasi dengan bantuan teknologi. Terciptanya suatu metode pembelajaran yang baru karena adanya guru yang selalu berusaha untuk memberikan perubahan sesuai kemajuan zaman terkhusus dalam dunia pendidikan. Ketiga, dengan adanya IT di masa pembelajaran maka proses pembelajaran tidak harus tatap muka. Sejauh ini, proses 
pembelajaran dilaksanakan secara langsung, akibat adanya pandemi serta teknologi yang semakin canggih kini pembelajaran beralih menggunakan teknologi, yang mana proses pembelajaran dilaksanakan secara jarak jauh atau online melalui media pembelajaran yang berbasis teknologi. Kelima, terdapatnya sistem menginput data hasil penilaian yang menggunakan teknologi. Perngaruh adanya teknologi kini pengolahan data penilaian tidak usah kerepotan untuk menganalisis satu persatu sehingga membutuhkan waktu yang lama, tetapi dengan adanya teknologi pengolahan data penilaian menjadi sesuatu yang mudah untuk dilakukan dan membutuhkan waktu yang singkat yaitu dengan cukup menggunakan media teknologi seperti laptop maupun komputer yang dapat mengolah data sesuai aplikasi yang dibutuhkan dan tidak hanya mengolah data penilaian saja. Hasil dari suatu penelitianpun juga bisa memudahkan ketika menganalisis suatu hasil dengan menggunakan media teknologi. Keenam, terpenuhinya kebutuhan sarana dan prasarana dapat dipenuhi dengan cepat karena hadirnya teknologi. Di dalam bidang Pendidikan membutuhkan banyak hal yang harus dipersiapkan. Salah satunya adanya berkas - berkas soal ujian dan sebagainya hal itu membutuhkan suatu mesin foto copy untuk dapat mempercepat proses pengerjaan karena jumlah berkas ujian dan data lainnya tidak sedikit. Bayangkan saja apabila semua dilaksanakan secara manual maka akan membutuhkan waktu yang lama untuk menyelesaikannya. Tetapi berkat adanya teknologi yang semakin canggih semua yang dibutuhkan akan dapat dilaksanakan dengan waktu yang cepat. Terkhususnya dalam kegiatan pembelajaran, ada beberapa manfaat yang dapat diperoleh dari perkembangan IPTEK, yaitu: 1) Pembelajaran menjadi lebih efektif dan menarik. 2) Dapat menjelaskan sesuatu yang sulit atau Kompleks. 3) Mempercepat proses pembelajaran yang semula lama. 4) Menghadirkan peristiwa yang jarang terjadi. 5) Menunjukkan peristiwa yang berbahaya atau di luar jangkauan. (Yohannes, 2018)

\section{Pengaruh Negatif TI Terhadap Pendidikan :}

Pengaruh IT tidak hanya memberikan dampak positif dalam Pendidikan, tetapi juga memberikan dampak negatif yang akan ditimbulkan karena dengan perkembangan IT yang semakin canggih dan maju dalam jalannya proses pendudukan, (Sudibyo, 2011:182) antara lain: Pertama, akibat adanya teknologi atau e-lerning dalam pendidikan kini peran guru sebagai pendidik lambat laun akan tidak dipedulikan. Karena peserta didik yg sudah ketergantungan akan lebih mengandalkan internet karena merasa bahwa teknologi segalanya. Serta peserta didik akan lebih mempunyai sifat individual karena kurangnya pergaulan akibat yang dilaksanakan pembelajaran jarak jauh. Bahkan 
kemungkinan kurangnya etika sopan santun serta tidak mempunyai rasa kepedulian terhadap oranglain. Kedua, pengaruh teknologi tidak hanya memberikan dampak positif bagi pendidikan tetapi juga dapat memberikan dampak negatif yang dikhawatirkan seringnya mengakses internet maka peserta didik bukan malah menggunakan teknologi dengan baik tetapi malah mengakses hal-hal yang tidak seharusnya dibuka. Seperti halnya membuka video pornografi, beramin game yg berlebihan serta hal hal yang lain yang tidak diingin. Maka dari itu pengawasan serta bimbingan dalam menggunakan teknologi harus selalu diterapkan tentunya bagi orang tua. Ketiga, akibat menggunakan teknologi yang berlebihan atau bisa disebut information overlod yaitu selalu mencari informasi yang tidak ada habis-habisnya sehingga dapat mengakibatkan ketergantungan bahkan sampai rela menghabiskan waktunya hanya dengan bermain hp karena untuk mengumpulkan informasi atau bermain game yang akhirnya juga akan berdampak tidak baik yaitu menyangkut tentang pornografi dan akan dapat menghabiskan uang karena seringnya mengakses internet yang tidak ada habisnya. Hal ini karena efek dari kecanduan dalam dunia internet sampai rela menghabiskan uang buat beli kuota untuk bisa bermain geme dan mengakses hal lain yang tidak berguna untuk pembelajaran. Keempat, pelajar ataupun pula mahasiswa jadi pecandu dari keberadaan dunia maya secara kelewatan. Perihal ini dapat terjalin kala siswa/ mahasiswa tidak mempunyai perilaku skeptic dan kritis terhadap suatu perihal yang baru. Terlebih dalam konteks dunia maya (internet) mereka secara tidak langsung sudah masuk di dalam dunia yang over free, hingga sangat berarti terdapatnya kedua perilaku di atas buat jadi benteng ataupun filter dari seluruh sumber data yang terdapat. Tidak hanya itu, yang tidak kalah berartinya yakni perhatian dan pengawasan dari orang tua pula sangat berfungsi dalam menanamkan nilai-nilai tentang suatu norma agama sebagai pedoman hidup. Kelima, Aksi kriminal (Cyber Crime). di dalam dunia pendidikan dapat menyebabkan suatu hal yang tidak baik misalnya pencurian dokumen ataupun asset penting tentang sebuah tatanan pendidikan yang sesungguhnya bersifat rahasia yang harus diamankan (dokumen mengenai ujian akhir atau negara) dengan melalui media internet. Keenam, memunculkan prilaku yang apatis pada setiap individu, baik bagi pelajar/ siswa/ mahasiswa ataupun pengajar/guru/ dosen. Hal ini bisa dilihat contohnya pada sebuah sistem pembelajaran yang bersifat virtual maupun e-learning. Di mana proses pembelajaran yang dilaksanakan tidak secara langsung atau tidak tatap muka anatar pendidik dan peserta didik, maka dapat terjadinya kurang efektifnya proses pembelajaran dalam virtual dan dapat terjadinya hasil yang tidak 
maksimal dikarenakan ketidakpedulian dalam suatu pembelajaran yang dilaksanakan secara online (Asmani, 2011)

\section{KESIMPULAN}

Berdasarkan penjelasan di atas dapat disimpulkan bahwa pengaruh penguasaan IT guru terhadap kualitas pembelajaran di masa pandemi memiliki pengaruh yang cukup besar, di mana penguasaan IT dalam suatu pembelajaran kini menjadi suatu hal yang penting apalagi disituasi pandemi saat ini. Lewat teknologi informasi serta komunikasi dapat mempengaruhi pembelajaran jadi lebih efektif dan efisien. Pengaruh IT dalam bidang pendidikan yang sekarang berkembang sangat pesat ini, mampu digunakan buat jadi penunjang di dalam terselenggaranya proses belajar mengajar secara jarak jauh. Sebab teknologi memiliki peran yang sangat penting di masa pandemi seperti ini. Karena seluruh kegiatan yang semula dilakukan secara langsung saat ini beralih hampir seluruh proses dilakukan dengan menggunakan teknologi. Kemudian pengaruh IT terhadap guru dapat menyebabkan proses pembelajaran tidak terhambat.

Guru selaku pelaku utama pendidikan harus mampu melakukan inovasi serta mempraktikkan kemajuan teknologi supaya pembelajaran mengasyikkan serta tidak menjenuhkan. Apabila seorang guru sudah pandai menguasai IT maka kompetensi pedagogiknya tidak akan jadi masalah serta pembelajaran yang diterapkan akan jauh lebih kreatif dan inovatif. Maka dari itu penguasaan IT menjadi hal yang penting bagi seorang guru untuk menciptakan lancarnya proses pembelajaran. Tidak hanya IT saja yang mempengaruhi peningkatan pedagogik tetapi lamanya pengalaman guru mengajar. Karena semakin lama pengalaman guru dalam mengajar maka semakin baik pula proses mengajarnya dan tentunya semakin profesional serta dapat dipercaya dengan baik untuk menjalankan tugas-tugas yang diamanatkan. Peneliti menyimpulkan bahwa yang dapat mempengaruhi kompetensi pedagogik ialah penguasaan IT serta lamanya pengalaman mengajar guru tersebut.

Pengaruh IT dalam bidang Pendidikan tidak hanya memiliki pengaruh yang positif saja melainkan memiliki pengaruh yang negatif. Di anatranya pengaruh yang positif IT dalam bidang pendidikan ialah munculnya jaringan internet, laboratorium komputer di sekolah dan teknologi lainnya merupakan suatu sumber pembelajaran dan media pendidikan. Adanya teknologi membuat inovasi bagi pendidik untuk terus menggali ilmu pengetahuan supaya pembelajaran tidak meluluh yang diajarkan oleh guru saja. Adanya IT memunculkan metode2 pembelajaran yang lebih canggih guna memudahkan guru serta 
siswa dalam proses pembelajaran dan lainnya. Sedangkah pengaruh negatifnya ialah Akibat adanya teknologi atau e-lerning dalam pendidikan kini peran guru sebagai pendidik lambat laun akan tidak dipedulikan. Karena peserta didik yg sudah ketergantungan akan lebih mengandalkan internet karena merasa bahwa teknologi segalanya. Serta peserta didik akan lebih mempunyai sifat individual karena kurangnya pergaulan akibat yang dilaksanakan pembelajaran jarak jauh. Bahkan kemungkinan kurangnya etika sopan santun serta tidak mempunyai rasa kepedulian terhadap oranglain

\section{REFERENSI}

Ahsani, E. L. F. 2020. "Strategi Orang Tua dalam Mengajar dan Mendidik Anak dalam Pembelajaran At The Home Masa Pandemi Covid-19”. JurnalAl_Athfal. Vol. 3 No. 1. 37-46.

Hamidaturrohmah\&Mulyani. 2020. "Strategi Pembelajaran Jarak Jauh Siswa Berkebutuhan Khusus Di Sd Inklusi Era Pandemi Covid-19". Elementary Islamic Teacher Journal. Vol. 8. No. 2. 247-278 Diakses di : http://journal.iainkudus.ac.id/index.php/elementary

Ibnu Rusydi. 2017. "Peranan Perkembangan Teknologi Informasi Dan Komunikasi Dalam Kegiatan Pembelajaran Dan Perkembangan Dunia Pendidikan". Jurnal Warta Edisi : 53 ISSN : 1829 - 7463

Marryono Jamun, Yohannes. 2018. “Dampak Teknologi Terhadap Pendidika”. Jurnal Pendidikan dan Kebudayaan Missio, Vol. 10, No. 1.

Nurhayati, T. (2016). Problematika Guru dalam Menguasai TIK (Teknologi Informasi dan Komunikasi) pada Pembelajaran Pendidikan Agama Islam dan Solusinya di MI Al-Asy'ari Kuniran Batangan Kabupaten Pati. [Skripsi]: Fakultas Ilmu Tarbiyah dan Keguruan Universitas Islam Negeri Walisongo. Semarang.

Putro, Khamim Zarkasih, Muhammad Adly Amri, Nuraisah Wulandari, and Dedek Kurniawan. "Pola Interaksi Anak Dan Orangtua Selama Kebijakan Pembelajaran Di Rumah.” Fitrah: Journal of Islamic Education (FJIE) 1, no. 1 (2020):

126. https://jurnal.staisumateramedan.ac.id/index.php/fitrah/article/view/12/8

Rahmayanti. 2015. "Penggunaan Media It Dalam Pembelajaran". Jurnal Jurnal Ilmiah CIRCUIT Vol. 1 No. 1.

Sudibyo, Lies. 2011. "Peranan dan Dampak Teknologi Informasi dalam Dunia Pendidikan di Indonesia". Jurnal WIDYATAMA Universitas Veteran Bangun Nusantara Sukoharjo. Vol. 20, No.2: 175-185. 
Sukmawati, Nensia. The Role of Google Classroom in ELT. Int J Educ Vocat Stud. 2019;1(2):142-5.

Suryana, D. (2012).Mengenal Teknologi. Jakarta: Gramedia.

Tekege, M. (2017). Pemanfaatan Teknologi Informasi dan Komunikasi dalam Pembelajaran SMA YPPGI Nabire. Jurnal Teknologi dan Rekayasa, 2(1), 4058. 